\title{
NOTES AND DISCUSSIONS
}

\author{
RELIGION'S REPLY TO ECONOMICS.
}

The capitalistic system of industry is under fire. The attack is being pressed on many sides, but mainly from two conspicuous points of vantage.

In the first place, capitalism is being assailed from the standpoint of efficiency. Its production of wealth is wasteful both of natural and human resources; and its distribution of the product on the basis of service rendered falls short of justice. The principle of competition has broken down. Instead of a delicately balanced system working automatically and without friction and disorder, the industrial world holds together only because of the necessary intrusion of such artificial elements as organized capital, organized labor, political regulation, and social ownership.

In the second place, capitalism is being attacked from the side of morals and religion. The system of private ownership and wage-labor is not only inefficient, but inhumane and materialistic. Its cruelty is seen in such commonplace accompaniments of its activity as child-labor, sweat-shops, tenements and slums, unsanitary factories, unguarded machinery, industrial accidents and diseases, twelvehour days and seven-day weeks of labor; conditions which have been abolished or bettered within recent years, mainly by the interference and command of the people, acting through the instrumentalities of democratic government. Nor need I enlarge upon the materialism fostered by our modern industrial life. If one were to try to invent a system, says Prof. Rauschenbusch, in his "Christianity and the Social Crisis," which should foster covetousness to the highest degree, one could not improve upon our present order of things. Capitalism stands indicted before the bar of religion because it is at bottom selfish, and selfishness is the essence of sin.

At a time when capitalism is thus condemned from the sides both of efficiency and of morals, it is not surprising perhaps that there are few to-day so mean as to do the system reverence. Now and then, however, a valiant voice is lifted; and such a voice do we have in Prof. Carver's able and effective little book, entitled "The Religion Worth Having."1 Essaying to answer the specific question, "Is religion of any use?" and thus to enter the religious field for the first time, the author soon finds himself back upon his old familiar economic stamping ground; and his book, therefore, becomes nothing more or less than a challenge to the two-fold criticism of capitalism which I have outlined above. Life, to Prof. Carver, is fundamentally a struggle, first a struggle "among social groups," and, secondly, a struggle among the individuals in each group, "modified, controlled and directed so as to promote the efficiency of the group in its inter-group struggle." The object of this struggle is the "control over the forces of nature;" and, through this control, of course, "dominion over the rest of mankind as mankind has ... dominion over the rest of the animal creation." This object will be

"Carver, T. N., The Religicn Worth Having, pp. vii, 140. Price,\$1.00. New York: Macmillan Company, 1911. 
attained by that "group which so regulates the struggle between its individuals as to secure the largest measure of success to those who strengthen the group most, and to bring poverty, failure or punishment to those who strengthen it least." Those "strengthen the group most" who have the largest fund of productive energy and the largest measure of productive efficiency. These men can be best discovered by the open struggle within the group of "economic competition," just as the best runners can be discovered by a race. Capitalism, in other words, is not only a nice test of the individuals, but it is at the same time a certain means of "getting the economic resources of the nation into the hands of those who can handle them most productively," and of bringing "failure and poverty to those unfortunate individuals who are not worth their keep!" It is the parable of the Talents all over again - "to him that hath shall be given, and from him that hath not shall be taken away even that which he hath."

Here is Prof. Carver's answer to the charge that capitalism is inefficient. It is obviously a reassertion in the baldest terms of the old economic individualism of the Manchester School. "The genius has never arisen," he says, "who could even suggest a way of distributing the wealth or the places of responsibility in a nation without a struggle of one kind or another as a test." It would be interesting to pause here and question the validity of such a restatement as this of the old political economy. We should like to ask if the existing inequalities of wealth, and of the ownership and control of the resources of nations, are commensurate in any sense with the productive energy and efficiency of the individuals concerned? We should like to inquire if artificial monopolies, special privileges, and industrial despotisms are not the inevitable accompaniments of such a struggle, and if the attempt to eliminate these extraneous factors in the situation by social control is not itself the very beginning of the end of that "economic competition" which the Professor lauds so highly? We should like to debate the problem of that poverty, for which, as Dr. Devine puts it in his "Misery and Its Causes," "the individual who suffers is not responsible, but which is not beyond the control of society." We should like to ask if the figures of the army, which Prof. Carver uses with such approval, are not the perfect picture of the socialized as contrasted with the individualistic group, wherein all competition between the individuals, composing the group, for purely individual ends, is eliminated, in favor of a rigorous co-operative enterprise for the social ends. We should like to question the Professor's cynical distrust of democracy, his utter lack of sympathy with the aspirations of labor, his contemptuous consignment of the poor to the rubbish heap, as those who have not "met the economic test of performance" and are therefore "not worth their keep." Especially should we like nothing better than to compare this statement of the old philosophy of individualism with the new philosophy of socialization as forecasted, if not actually set forth and justified, by Prof. Taussig's remarkable "Principles of Political Economy." But for all this we have no space. We must be content with pointing out that Prof. Carver has answered the charge that capitalism is inefficient by reaffirming the old principle of "economic competition," and is far from convincing in his statement.

Of more immediate concern to us is the author's answer to the second charge, that capitalism is immoral and irreligious-un-Christian, we might add-which 
constitutes the real burden of his message. Prof. Carver meets this indictment by redefining religion in terms of his political economy. "That is the best religion," he says "which (1) acts most powerfully as a spur to energy, and (2) directs that energy most productively." "The religion worth having," he says in another place, "is the religion which will enable its adherents to be fruitful and multiply and people the earth and subdue it and have dominion over it." "The religion worth having is the religion which enables the people and nations which adopt it to survive in competition with peoples and nations possessing any other gift of religion. The religion is not worth having which brings failure in this physical and practical sense, which would unfit for the struggle for dominion the peoples and nations which adopt it, and cause them to succumb to the superior surviving power of other peoples." The gospel of religion, in other words, is the "workbench" gospel, which fosters productive energy; and the great sin against which such a gospel must be directed is that of the pig-trough, which tempts men to enjoy rather than to produce. The true church is "the Fellowship of the Productive Life;" and that this church will be separated from the masses is "a normal and economic result," since "people with such a religion could scarcely help prospering out of proportion to peoples who waste their energies in sin and dissipation." "This aspect of the separation of the church from the masses," says Prof. Carver, "is displeasing to those who are beaten, and their natural resource is talk, muck-raking and palaver."

That this statement is one of amazing interest and value goes without saying. Here we have a perfectly frank and unblushing attempt to define the religion of capitalism not in the strange terms of a theology but in its own familiar terms of political economy. And that this definition sounds suspiciously like the promise of Satan when he revealed to Christ "the kingdoms of the world and all the glory of them" is not perhaps surprising. Here, it seems to me, we have a more impressive proof of the essentially irreligious character of the competitive system of industry, and its utter incompatibility with the religion of Jesus, than can be found in any of the writings of those who are out-and-out opponents of the whole business. Here is a religion which sees nothing more in the individual than a worker whose business it is to produce, and then use the surplus of his production "for further productive achievement, for a further conquest of the forces of nature and an extension of dominion over the world." Here is a religion which defines success in human living as a production of a surplus of material things over and above what is "necessary to sustain life," and a failure in human living as the production of merely enough for personal sustenance, or less.

Prof. Carver's religion, in short, knows nothing in the teaching of Jesus but the parable of the Talents, and finds in this the summation of the Christian gospel! It is a religion which fosters the prejudice of rank, the pride of class, and all the stupid pretensions of political and industrial aristocracy-a religion of the strong, the unscrupulous, the proud. But that it is a "religion worth having," or, in the last analysis, any religion at all, I would steadfastly deny. Religion has to do ultimately with spiritual and not material things, or rather it has to do with material things only as they affect the spiritual realities of life, which is of course very nearly. Religion is interested not in a man's material success, but in his spiritual integrity. Religion can be quite content if a man fails to gain any 
part of the world, if only he saves his own soul. Religion does not stop with the parable of the Talents, but passes on to other and higher truths which sprinkle the gospel pages from Matthew 1 to John 23. Religion believes that the workbench philosophy is sound and good, so far as it goes; but it believes that above and beyond this is the family or home philosophy, which represents men, not so much as toilers competing at the work-bench, as brothers in a home, living in the ideal of "from each according to his ability, to each according to his need." Religion, let me emphasize again, must be as practical as Prof. Carver would" have it. It must concern itself very immediately with the world in c.ll its industrial and political phases. But this it must do, not for the purpose of capturing and controlling the world as it is, but rather for the purpose of remaking it, reforming it, refashioning it, after the heart's desire, that the bodies of men may not be bruised, and the souls of men destroyed. What true religion wants is not dominion for the sake of further conquest, but dominion only for the sake of soul-emancipation. Men must be free to realize the divine possibilities of their beings. They must be free to grow and aspire and love.

New York City.

John Haynes Holmes. 